\title{
Kan preeklampsi forutsies?
}

\author{
Forskning har de siste årene vist lovende resultater for sirkulerende angiogenetiske faktorers evne til \\ å predikere preeklampsi. Det er store kommersielle interesser knyttet til slike tester. Hvilken rolle spiller \\ angiogenetiske faktorer i selve utviklingen av preeklampsi, og hva er dokumentasjonen for deres prediktive \\ verdi og eventuelle klinisk nytte?
}

Kommentaren er en del av førsteforfatters profesjonsoppgave ved Det medisinske fakultet, Universitetet i Oslo, og er basert på deler av en engelskspråklig oversiktsartikkel i Pregnancy Hypertension (1).

Preeklampsi (svangerskapsforgiftning) forekommer i minst 3-4\% av alle svangerskap og er en potensielt alvorlig svangerskapskomplikasjon, spesielt i land med dårlig svangerskapsovervåking. Årlig dør om lag 50000 kvinner av preeklampsi på verdensbasis. Preeklampsi defineres som nyoppstått hypertensjon og proteinuri utviklet etter svangerskapsuke 20. De kjente kliniske risikofaktorene for å utvikle preeklampsi (overvekt, alvorlig preeklampsi i tidligere svangerskap, førstegangssgraviditet, høy alder hos mor, diabetes etc.) har begrenset prediktiv verdi. Ultralydundersøkelse av blodstrømmen i a. uterina (med dopplermetodikk) i svangerskapet er heller ikke optimalt som screening av lavrisikogravide for utvikling av svangerskapskomplikasjoner (preeklampsi og fostertilveksthemming) (1).

Det finnes ingen spesifikk behandling av preeklampsi, annet enn fjerning av det syke organet (placenta) og dermed forløsning. Ved erkjent preeklampsi vil mor og foster bli nøye overvåket for å finne beste tidspunkt for forløsningen. Alvorlig preeklampsi vil ofte føre til prematur forløsning, med de komplikasjoner dette medfører for barnet. Preeklampsi har også vist seg å være en risikofaktor for senere utvikling av hjerte- og karsykdom, det gjelder både den gravide og hennes barn (1).

Det er flere grunner til at det ville være nyttig med en pålitelig biomarkør for preeklampsi. Dersom man tidlig i svangerskapet kunne identifisere gravide med økt risiko, kan man følge disse svangerskapene nøye slik at man kan optimalisere forløsningstidspunktet og dermed helsen til mor og barn. I tillegg ville slike biomarkører sannsynligvis reflektere noe av patofysiologien bak preeklampsi og dermed forhåpentligvis bidra til å finne nye profylakse- og behandlingsmuligheter. Ved klinisk erkjent preeklampsi kunne en biomarkør muligens også benyttes for å vurdere sykdommens alvorlighetsgrad, sammen med de tradisjonelle kliniske vurderingene av tilstanden hos mor og foster.

De siste årene har man satt søkelys på sirkulerende angiogenetiske faktorer som de beste prediktive biomarkører for preeklampsi. Målet med denne kommentaren er å beskrive disse faktorenes rolle i selve utvik- lingen av preeklampsi samt evaluere deres kliniske nytteverdi for å predikere tilstanden.

\section{Mulig rolle i utvikling av preeklampsi}

I 2003 ble det angiogenetiske proteinet sFlt 1 (soluble fms-like tyrosine kinase 1), også kalt VEGF-R1 (vascular endothelial growth factor receptor 1), foreslått som en endotelskadende faktor ved preeklampsi (2). VEGF (vascular endothelial growth factor) er den viktigste angiogenetiske vekstfaktoren og en viktig overlevelsesfaktor for vaskulært endotel. sFlt1-proteinet i morens sirkulasjon fungerer som «lokkedue» for de sirkulerende angiogenetiske faktorene VEGF og PlGF (placental growth factor) ved at disse molekylene bindes sFlt1, noe som gir lavere konsentrasjon av fritt sirkulerende VEGF og
Hittil har derfor ikke VEGF vært nyttig som prediktor for preeklampsi, men dette kan endres dersom det utvikles mer sensitive målemetoder (1).

$P l G F$. Noen studier har vist at lav maternell serumkonsentrasjon av PlGF i første trimester predikerer preeklampsi, mens dette $i$ andre studier ikke har vist prediktiv verdi. I de fleste studier har man imidlertid funnet at lav maternell PlGF-konsentrasjon i annet trimester predikerer utvikling av tilstanden. Lave PIGF-konsentrasjoner i første eller annet trimester predikerer også om barnet er lavvektig i forhold til svangerskapsalder (1).

sFlt1. De fleste studiene viser at høy maternell konsentrasjon av sFlt1 i annet trimester predikerer preeklampsiutvikling, og at høy sFlt1-konsentrasjon er best som prediktor for tidlig preeklampsiutvikling

\section{«Det finnes ingen spesifikk behandling av preeklampsi, annet enn fjerning av det syke organet (placenta) og dermed forløsning»}

PIGF. Dette kan føre til utvikling av hypertensjon, proteinuri og dermed klinisk preeklampsi, sannsynligvis via forstyrret VEGFaktivering av maternelt endotel med redusert aktivering av eNOS (endothelial nitrogen oxide synthase) og NO-produksjon (2). I 2006 foreslo den samme forskningsgruppen ved Harvard at et overskudd av sEng (soluble endoglin) også er involvert i utviklingen av preeklampsi $(3,4)$. Både sEng og sFlt1 produseres i større mengder fra morkaken ved klinisk preeklampsi enn i normotensive svangerskap.

Klinisk etablert preeklampsi karakteriseres ved lav maternell serumkonsentrasjon av fritt PIGF samt høy serumkonsentrasjon av sFlt1 og sEng sammenliknet med det som er tilfellet i normotensive svangerskap. Forhøyet konsentrasjon av sFlt1 og lav konsentrasjon PlGF er også funnet i navlestrengsblod hos nyfødte fra preeklamptiske svangerskap (1).

\section{Angiogenetiske faktorer i blod}

$V E G F$. Den mest brukte ELISA-metoden for å måle VEGF er ikke sensitiv nok for de lave VEGF-konsentrasjonene hos gravide. (med forløsning før svangerskapsuke 37) og der fostertilveksten er affisert. Нøy sFlt1-konsentrasjon er også funnet i svangerskap som senere kompliseres av intrauterin tilveksthemming uten samtidig hypertensjonsutvikling (1).

Når det gjelder maternelle sFlt1-konsentrasjoner i første trimester, er det sprikende funn. Levine og medarbeidere fant ingen prediktiv verdi av sFlt1-konsentrasjonen i første trimester (5), det samsvarer med flere andre studier (1). I en større populasjonsbasert studie fra Norge viste vi at lav sFlt1-konsentrasjon i første trimester predikerer tidlig preeklampsiutvikling (der de gravide forløses prematurt) (6). Dette funnet er senere bekreftet i to studier $(7,8)$. Forskjellig tidspunkt for prøvetaking innen første trimester kan ha bidratt til disse ulike konklusjonene. Etter første trimester er den føtomaternelle placentasirkulasjonen etablert, og økningen av sFlt1-konsentrasjonen i maternelt blod skyldes antakelig den dårlige remodelleringen av maternelle blodkar til placenta og dermed økt oksidativt stress og økt placentaproduksjon av sFlt1.

$s E n g$. Forhøyet maternell serumkonsen- 
trasjon av sEng er påvist 2-3 måneder før klinisk preeklampsiutvikling (3). Нøy serumkonsentrasjon av sEng i første trimester har ikke vært prediktivt for preeklampsi, med unntak av i to studier $(1,7)$. Imidlertid er det i mange studier vist at høy maternell serumkonsentrasjon $i$ annet trimester er prediktivt for preeklampsiutvikling, spesielt tidlig og alvorlig preeklampsiutvikling (1, 3, 7-11).

Ratioer og longitudinell prøvetaking. Forholdet mellom «proangionetiske» og «antiangiogenetiske» faktorer (VEGF og PlGF i forhold til sFlt1 og sEng) ser ut til å være gode mål for å vurdere preeklampsirisikoen, spesielt gjelder det utvikling av tidlig preeklampsi $(1,3,6,11)$. Ratioen sFlt1/PlGF har vist seg å være bedre prediktor for preeklampsiutvikling enn sFlt1 eller PIGF målt hver for seg (1). Vi fant at liten stigning i PlGF-konsentrasjonen og stor stigning i sFlt1-konsentrasjonen fra første til annet trimester økte risikoen for preeklampsiutvikling 35 ganger så mye som stor PlGFstigning og liten sFlt1-stigning (6).

\section{Angiogenetiske faktorer i urin}

sFlt1 har molekylstørrelse på 100 kDa, som er for stort til å filtreres til urinen $i$ friske nyrer. PlGF og VEGF er mindre proteiner $(\sim 30 \mathrm{kDa}$ og $\sim 45 \mathrm{kDa})$ og filtreres til urinen (1). VEGF produseres lokalt i nyrene, og urinkonsentrasjonen av VEGF reflekterer derfor ikke nødvendigvis konsentrasjonen i maternelt blod. Buhimschi og medarbeidere har imidlertid vist at sFlt1og VEGF-konsentrasjonen i urin er forhøyet ved alvorlig preeklampsi, sannsynligvis pga. kombinert glomerulær lekkasje og lokal økt produksjon i nyrene av begge proteinene (12).

I flere studier er det påvist lav PlGF-konsentrasjon i urinen ved etablert preeklampsi samt at lav konsentrasjon i annet trimester predikerer tilstanden (12-14), spesielt gjelder det tidlig preeklampsiutvikling og tilveksthemming $(13,14)$. Buhimschi og medarbeidere har vist at sFlt1/PlGF-ratioen i urinen er høy ved alvorlig preeklampsi og korrelerer med serumkonsentrasjon av urinsyre, systolisk og diastolisk blodtrykk, grad av proteinuri og tilveksthemming (12). De fant nylig at høy urinkonsentrasjon av sEng også predikerte preeklampsiutvikling, dog med lav sensitivitet og spesifisitet, og konkluderte med at sFlt1/PIGF-ratioen i urin bedre predikerer preeklampsi (15). sFlt1 i urin er ikke målbart tidlig i svangerskapet, og VEGF i urin kan ikke predikere preeklampsi (13).

\section{Konklusjon}

Det finnes i dag få metaanalyser der man har evaluert angiogenetiske faktorers prediktive evne når det gjelder preeklampsiutvikling. Det er vanskelig å sammenlikne primærstudiene fordi prøvetakningstidspunktet og populasjonsgruppene varierer. En sammenstilling av flere faktorer er vist å forbedre prediksjonsevnen, slik som kombinasjonen av den gravides obstetriske anamnese, blodstrømsmålinger av a. uterina samt PlGFog sFlt1-konsentrasjoner i blod (1).

Generelt har dagens tilgjengelige tester av de sirkulerende angiogenetiske faktorene for lav sensitivitet og spesifisitet til å kunne brukes som screening for å predikere preeklampsi. De blodbaserte testene er i dag bedre prediktorer enn de urinbaserte $(5,6$, 15). Kvinnene som utvikler preeklampsi er en heterogen gruppe, og det er sannsynligvis vanskelig å finne én biomarkør som vil kunne predikere utvikling av preeklampsi generelt. I videre studier bør det legges vekt på konsentrasjonsendringer av angiogenetiske faktorer over tid samt den kombinerte prediktive verdien av kliniske risikofaktorer og biomarkører. En god prediktiv biomarkør vil kunne være nyttig for å selektere og følge opp høyrisikopasienter i profylaktiske studier. Det endelige målet med biomarkørbruk er imidlertid ikke å predikere og redusere forekomsten av preeklampsi per se, men å bedre morens og barnets helsetilstand både på kort og på lang sikt. Det er fremdeles lang vei til dette målet.

\section{Nora Langballe Rosseland}

Det medisinske fakultet

Universitetet i Oslo

\section{Mark Lewis Belandres Barbero}

\section{Annetine Staff}

annetine.staff@uus.no

Gynekologisk avdeling og fødeavdelingen

Oslo universitetssykehus, Ullevål

0407 Oslo

\section{Oppgitte interessekonflikter: Ingen}

Litteratur

1. Staff AC. Circulating predictive biomarkers in preeclampsia. Pregnancy Hypertension: An International Journal of Women's Cardiovascular Health 2011; 1: 28-42

2. Maynard SE, Min JY, Merchan J et al. Excess placental soluble fms-like tyrosine kinase 1 (sFlt1) may contribute to endothelial dysfunction, hypertension, and proteinuria in preeclampsia. J Clin nvest 2003; 111: 649-58.

3. Levine RJ, Lam C, Qian C et al. Soluble endoglin and other circulating antiangiogenic factors in preeclampsia. N Engl J Med 2006; 355: 992-1005.

4. Venkatesha S, Toporsian M, Lam C et al. Soluble endoglin contributes to the pathogenesis of preeclampsia. Nat Med 2006; 12: 642-9.

5. Levine RJ, Maynard SE, Qian C et al. Circulating angiogenic factors and the risk of preeclampsia. N Engl J Med 2004; 350: 672-83.

6. Vatten LJ, Eskild A, Nilsen TI et al. Changes in circulating level of angiogenic factors from the first to second trimester as predictors of preeclampsia. Am J Obstet Gynecol 2007; 196: 239-6.

7. Kusanovic JP, Romero R, Chaiworapongsa $T$ et al. A prospective cohort study of the value of maternal plasma concentrations of angiogenic and antiangiogenic factors in early pregnancy and midtrimester in the identification of patients destined to develop preeclampsia. J Matern Fetal Neonatal Med 2009: 22: 1021-38.

8. Erez O, Romero R, Espinoza J et al. The change in concentrations of angiogenic and anti-angiogenic factors in maternal plasma between the first and second trimesters in risk assessment for the subsequent development of preeclampsia and smallfor-gestational age. J Matern Fetal Neonatal Med 2008; 21: 279-87.

9. Rana S, Karumanchi SA, Levine RJ et al. Sequential changes in antiangiogenic factors in early pregnancy and risk of developing preeclampsia. Hypertension 2007; 50: 137-42.

10. Kim YN, Lee DS, Jeong DH et al. The relationship of the level of circulating antiangiogenic factors to the clinical manifestations of preeclampsia. Prenat Diagn 2009; 29: 464-70.

11. Masuyama H, Segawa T, Sumida Y et al. Different profiles of circulating angiogenic factors and adipocytokines between early- and late-onset preeclampsia. BJOG 2010; 117: 314-20.

12. Buhimschi CS, Norwitz ER, Funai E et al. Urinary angiogenic factors cluster hypertensive disorders and identify women with severe preeclampsia. Am J Obstet Gynecol 2005; 192: 734-41.

13. Levine RJ, Thadhani R, Qian C et al. Urinary placental growth factor and risk of preeclampsia. JAMA 2005; 293: 77-85

14. Aggarwal PK, Jain V, Sakhuja V et al. Low urinary placental growth factor is a marker of preeclampsia. Kidney Int 2006; 69: 621-4.

15. Buhimschi CS, Baumbusch MA, Dulay AT et al. The role of urinary soluble endoglin in the diagnosis of pre-eclampsia: comparison with soluble fms-like tyrosine kinase 1 to placental growth factor ratio. BJOG 2010; 117: 321-30.

Mottatt 22.12. 2010, første revisjon innsendt 14.2 . 2011 godkjent 17.3. 2011. Medisinsk redaktør Siri Lunde. 